\title{
COOPERATION AND THE INTERNATIONAL CRIMINAL COURT: THE FREEZING, SEIZING AND TRANSFER OF ASSETS FOR THE PURPOSE OF REPARATIONS
}

\author{
Carla Ferstman
}

\section{Contents}

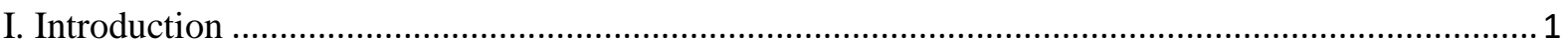

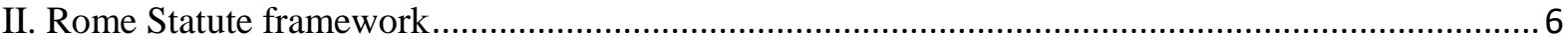

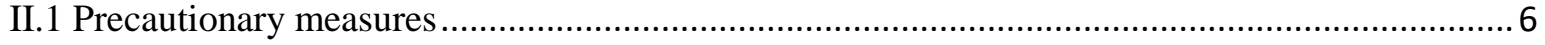

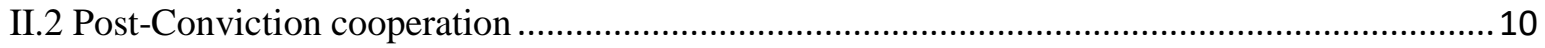

III. Particular problem areas in the context of application................................................................... 11

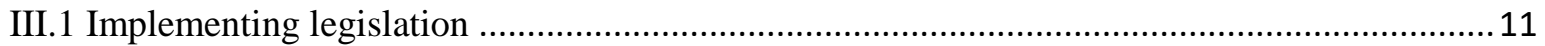

III.2 The disposition of assets subject to sanctions regimes and other parallel freezing orders .......12

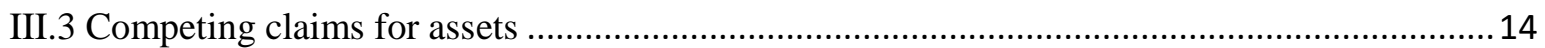

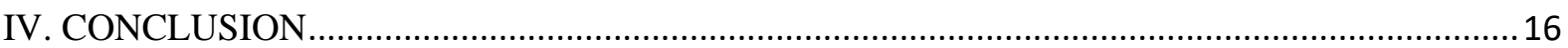

\section{Introduction}

Reparation to victims is an important innovation of the Rome Statute. Article 75 of the Statute enables the International Criminal Court (ICC) to award reparations to victims who suffered harm as a result of the acts of a convicted perpetrator. Reparations can be individual or collective or both, and may take the form of inter alia, restitution, compensation and/or rehabilitation. ${ }^{1}$ At the time of writing, the ICC has awarded reparations in respect of victims following the conviction of Thomas Lubanga Dyilo. The Trial Chamber issued a decision on the principles and the process to be implemented for reparations to victims in that case in 2012, ${ }^{2}$ and in March 2015, the Appeals Chamber issued its judgment on the appeals of that decision. ${ }^{3}$ A second reparations process was also underway in the Germain Katanga case, following his conviction on 7 March $2014^{4}$ and sentence on 23 May 2014. ${ }^{5}$ On 15 December 2014, the Registry filed a report on the applications for reparations that had been received in

\footnotetext{
${ }^{1}$ Article 75(1) of the Rome Statute.

${ }^{2}$ ICC, Prosecutor v. Thomas Lubanga, Decision establishing the principles and procedures to be applied to reparations, ICC-01/04-01/06, 7 August 2012.

${ }^{3}$ ICC, Prosecutor v. Thomas Lubanga Judgment on the appeals against the "Decision establishing the principles and procedures to be applied to reparations" of 7 August 2012 with AMENDED order for reparations (Annex A) and public annexes 1 and 2, ICC-01/04-01/063129, 3 March 2015

${ }^{4}$ ICC, Prosecutor v. Germain Katanga, Jugement rendu en application de l'article 74 du Statut, ICC-01/04-01/07-3436, 7 March 2014.

${ }^{5}$ ICC, Prosecutor v. Germain Katanga, Décision relative à la peine (article 76 du Statut), ICC-01/04-01/07-3484, 23 May 2014.
} 
the Katanga case. ${ }^{6}$ Subsequently, the Trial Chamber set a deadline for interested States or other interested persons to apply for leave to file submissions relating to reparations, ${ }^{7}$ which was thereafter extended. ${ }^{8}$

The ICC Appeals Chamber has made clear that 'a convicted person's liability for reparations must be proportionate to the harm caused and, inter alia, his or her participation in the commission of the crimes for which he or she was found guilty, in the specific circumstances of the case'. ${ }^{9}$ The Appeals Chamber also determined that indigence is not an obstacle to the imposition of liability for reparations on the convicted person, because the assets of the convicted perpetrator may in principle be located and seized at some future date. ${ }^{10}$ These are important statements of principle, and make clear that to the extent possible, the ICC understands its role as far more than symbolic; the obligation of a convicted perpetrator to afford reparations to victims is understood in much the same way as States' obligations to afford reparations for internationally wrongful acts including violations of human rights. The jurisprudence and relevant international principles concerning State responsibility affirm that the quantum and/or quality of reparations must reflect the harm caused and adequately redress the suffering of victims. ${ }^{11}$

The ICC Appeals Chamber's holding that reparations need to be proportionate to the harm is perhaps both a blessing and a curse. It makes clear that the ICC understands its role in reparations as larger, or more significant, than merely providing symbolic gestures or charity to eligible victims. ${ }^{12}$ But at the same time, it underscores the importance of the ICC's cooperation regime for the tracing, freezing, seizing and eventual transfer of assets for the benefit of reparations. If that cooperation regime works, then the ICC's proportionate reparations awards have a chance of being enforced, at least in those instances when there are assets to be had and the perpetrates are not impecunious. If the cooperation regime fails, then

\footnotetext{
${ }^{6}$ ICC, Prosecutor v. Germain Katanga, Registry Report on Applications for Reparations in accordance with Trial Chamber II's Order of 27 August 2014, ICC-01/04-01/07-3512, 15 December 2014.

${ }^{7}$ ICC, Prosecutor v. Germain Katanga, Scheduling order for interested States or other interested persons to apply for leave to file submissions pursuant to Article 75 of the Statute, ICC-01/04-01/07-3516, 21 January 2015.

${ }^{8} \mathrm{ICC}$, Prosecutor v. Germain Katanga, Order extending the deadline for interested States and other interested persons to apply for leave to file submissions pursuant to Article 75 of the Statute, ICC-01/04-01/07-3518, 2 February 2015.

${ }^{9}$ ICC, Prosecutor v. Thomas Lubanga, Appeals Chamber judgment, 3 March 2015, para. 118.

${ }^{10}$ Ibid, paras. 102-105.

${ }^{11}$ See, e.g., Permanent Court of International Justice, Fourteenth (Ordinary) Session, The Factory at Chorzow (Claim for Indemnity) (The Merits), Germany v Poland, Judgment No.13, 13 September 1928, File E.c.XIII., Docket XIV: I., para. 73; UN Basic Principles and Guidelines on the Right to a Remedy and Reparation for Victims of Gross Violations of International Human Rights Law and Serious Violations of International Humanitarian Law ('UN Basic Principles and Guidelines'), Adopted by General Assembly resolution 60/147, 16 December 2005.

${ }^{12}$ See, in contrast, the approach taken by the Trial Chamber in the Lubanga case, which took a much more restricted approach to reparations. ICC, Prosecutor v. Thomas Lubanga, Decision establishing the principles and procedures to be applied to reparations, 7 August 2012.
} 
the ambitions of the ICC in regards to reparations risk being incapable of realising their full potential. ${ }^{13}$ Reparations awards might end up being another form of 'lip-service' to victims. The Assembly of States Parties noted in its resolution on cooperation adopted in December 2014, that as 'the identification, tracing and freezing or seizure of any assets of the convicted person are indispensable for reparations, it is of paramount importance that all necessary measures are taken to that end. ${ }^{14}$ This is further underscored in its resolution on cooperation adopted at the same time. ${ }^{15}$

This paper outlines what the cooperation regime for the recovery of property and assets looks like, how it is supposed to work, and how it works in practice. With respect to the Court's practice, some of the filings and orders issued by the Court remain confidential. As such, it can be difficult to piece together a clear picture of what has happened and why. However, increasingly, there is a practise of de-classifying documents once the need for their confidentiality ceases. Thus, albeit with some delay, the Court's approach to assets and related orders is slowly becoming more apparent.

To date, it is probably fair to say that the regime has under-performed, for a combination of reasons. Sometimes, property or assets of accused persons has simply not been located because the persons are impecunious; there are no assets to be found. This has been the case with respect to Thomas Lubanga Dyilo, the first person to be convicted by the Court, and as argued by the Registry, is likely to be the norm: ${ }^{16}$ 'The situation where the accused had no assets for reparations [is] considered the normal situation; the situation where he had sufficient funds available, the exception. ${ }^{, 17}$ However, in many other instances, assets have not been successfully located for arguably other reasons that the Court can progressively work to address and/or States have not adequately or sufficiently cooperated with requests for the location and freezing of assets, as they are required to do. The reasons for these latter failings stem from:

\footnotetext{
${ }^{13}$ Certainly, the ICC's Trust Fund for Victims in the exercise of its full discretion may apply its voluntary resources to aid in the implementation of a reparations award, particularly where a convicted perpetrator is indigent. However, as has been determined by the Appeals Chamber in the Lubanga case, the trust fund is not obliged to use its funds in this way. See, ICC, Prosecutor v. Thomas Lubanga, Appeals Chamber judgment, 3 March 2015, paras. 111-114.

${ }^{14}$ Assembly of States Parties, Resolution on "Victims and affected communities, reparations and Trust Fund for Victims", ICCASP/13/Res.4, Adopted at the 12th plenary meeting, on 17 December 2014, by consensus, para. 10.

${ }^{15}$ Assembly of States Parties, Resolution on cooperation, ICC-ASP/13/Res.3, Adopted at the 12th plenary meeting, on 17 December 2014, by consensus, para. 22 .

${ }^{16}$ Prosecutor v. Thomas Lubanga Dyilo, Second Report of the Registry on Reparations, ICC-01/04-01/06-2806, 1 September 2011, paras. $10,21$.

${ }^{17}$ Ibid, para 128.
} 
i) The weak statutory framework with vaguely articulated State obligations particularly in respect of pre-conviction precautionary measures.

ii) Inadequate cooperation by States. Many States Parties have failed to set up the necessary domestic structures, appoint focal points to deal with eventual requests and remove legal or procedural barriers to cooperation including restrictive banking secrecy laws which might operate at the domestic or inter-State level. The failure to adequately and proactively address these areas has meant that the ground is not prepared for States to comply with cooperation requests that concern assets if and when those requests are made. Also, States' responses to actual requests that have made to date have invariably though with some notable exceptions, been weak, too slow or ineffectual. The Assembly of States Parties has underscored the importance of, and called on all States Parties to put in place and further improve, 'effective procedures and mechanisms that enable States Parties and other States to cooperate with the Court in relation to the identification, tracing and freezing or seizure of proceeds, property and assets as expeditiously as possible. ${ }^{18}$ In the Lubanga case, the Pre-Trial Chamber highlighted that 'existing technology makes it possible for a person to place most of his assets and moveable property beyond the Court's reach in only a few days. Therefore, if assets and property are not seized or frozen at the time of the execution of a cooperation request for arrest and surrender, or very soon thereafter, it is likely that the subsequent efforts of the PreTrial Chamber, the Prosecution or the victims participating in the case will be fruitless. ${ }^{19}$

iii) Inadequate attention and resources deployed to advance the issue and promote State cooperation by those Court organs with the mandate to so engage - the Office of the Prosecutor, the Registry and the Presidency. There is some indication that these areas are being increasingly prioritised however to date this has only produced minimal and piecemeal results. There is also a cyclical problem of cross-blaming, with a tendency for certain States to disparage the Court for imprecise or inadequately worded cooperation requests which then impede them from cooperating effectively and for Court organs to place emphasis on States'

\footnotetext{
${ }^{18}$ Assembly of States Parties, Resolution on cooperation, 17 December 2014, para. 23.

${ }^{19}$ Prosecutor v. Thomas Lubanga Dyilo, Decision on the Prosecutor's Application for Warrants of Arrest, Article 58, Annex II, ICC-01/04-

520-Anx2, 10 February 2006, para. 151.
} 
failures to progress national or transnational investigations, which arguably States are better placed to undertake. For instance, in 2011, the Court reminded that 'In some instances, the Court is not in possession of such required specific information regarding assets allegedly held by suspects on their territory and urges States Parties to complete to the extent possible the information contained in these requests which they may be able to access through national investigations. ${ }^{20}$ In 2012, a workshop was organised by the Bureau of the Assembly of States Parties' facilitator on cooperation, in cooperation with the Court, on the subject of cooperation between the Court and States with a special focus on requests for assistance in identification, freezing and seizing of assets and property. This workshop produced a number of practical recommendations to the Court as well as States to improve the prospects for the enforcement of cooperation requests. ${ }^{21}$

iv) Article $87(7)$ of the Rome Statute provides that 'Where a State Party fails to comply with a request to cooperate by the Court contrary to the provisions of this Statute, thereby preventing the Court from exercising its functions and powers under this Statute, the Court may make a finding to that effect and refer the matter to the Assembly of States Parties or, where the Security Council referred the matter to the Court, to the Security Council.' In the Kenyatta case, the Court has determined that "non-compliance arising from, inter alia, unjustified inaction or delay, or a clear failure to have in place appropriate procedures for effecting the cooperation, as required under Article 88 of the Statute, constitutes failure to comply under Article 87(7) of the Statute which may, depending upon the circumstances, warrant a finding of non-compliance and concomitant referral under the same article. The approach of the relevant State during the cooperation process, as well as of the party seeking a finding under Article 87(7) of the Statute, may be of particular importance in finding whether there has been the standard of good faith cooperation required from State Parties. ${ }^{22}$ However, because of the vaguely worded State obligations in respect to the recovery of property and assets, it has been difficult to identify clear instances in which a State Party has objectively failed to cooperate, and thus neither ICC chambers have

\footnotetext{
${ }^{20}$ Assembly of States Parties, Report of the Court on cooperation, ICC-ASP/10/40, 18 November 2011, para. 34

${ }^{21}$ ICC, Summary of the 1 October 2012 workshop on cooperation, including proposals and suggestions from the participants, in Assembly of States Parties, Report of the Bureau on cooperation, ICC-ASP/11/28, 23 October 2012, Annex 2.

${ }^{22}$ The Prosecutor v. Uhuru Muigai Kenyatta, Decision on Prosecution's application for a finding of non-compliance under Article 87(7) of the Statute, ICC-01/09-02/11-982, 3 December 2014, para 42.
} 
identified nor has the Assembly of States Parties deployed any political tools to respond to instances of non-cooperation in respect of requests pertaining to assets (unlike the actions, albeit limited, that have been taken to address the problem of States' failure to cooperate with the Court on the enforcement of arrest warrants and surrenders to the Court of accused persons). ${ }^{23}$

v) Far too limited engagement by most victims' legal representatives to pursue assets. Under the statutory framework it is the Office of the Prosecutor that is tasked with the investigation of the property and assets of accused persons. Nonetheless, legal representatives for victims could do more to press the Prosecutor to act or to encourage the relevant chamber to issue cooperation requests on its motion.

The paper considers some of these failings and also sets out the possible ways in which to strengthen the asset recovery regime, taking into account the many constraints.

\section{Rome Statute framework}

The Rome Statute and the associated rules of procedure and evidence outline a framework for the recovery of assets and property for the purposes of reparations to victims. States Parties are obligated to cooperate in the 'identification, tracing and freezing or seizure of proceeds, property and assets and instrumentalities of crimes for the purpose of eventual forfeiture' ${ }^{24}$ As will be described, this framework lacks clarity in many areas, which can impact on the effectiveness of requests to States and the capacity for their enforcement.

\section{II.1 Precautionary measures}

The ability for courts themselves, or States collaborating with them, to locate, freeze and seize assets of accused persons on a precautionary or provisional basis is a vital opportunity to safeguard assets for eventual reparations proceedings. Sometimes, such procedures are designed to help secure custody over suspects who remain at large on the basis that curtailing them from accessing their own funds will force them into the open or encourage them to

\footnotetext{
${ }^{23}$ See e.g., Assembly of States Parties, Report of the Bureau on non-cooperation, ICC-ASP/13/40, 5 December 2014, which deals exclusively with cases of non-surrender.

${ }^{24}$ Article $93(1)(\mathrm{k})$ of the ICC Statute.
} 
surrender. The property and assets that are frozen might eventually be used to contribute to the costs of defence, property may be returned to the rightful owners and in some instances the assets may be used to fund reparations to victims.

Article 57(3)(e) of the Statute enables the Court to issue a request to States to take protective measures including freezing an accused person's assets for the purpose of forfeiture, in particular for the ultimate benefit of victims. The provision makes specific reference to Article 93(1)(k) of the Statute, indicating that protective measures under Article 57(3)(e) are made 'pursuant to' Article 93(1)(k). Rule 99(1) of the Rules of Procedure and Evidence specifies that: 'the Pre-Trial Chamber, pursuant to Article 57, paragraph 3(e), or the Trial Chamber, pursuant to Article 75, paragraph 4, may, on its own motion or on the application of the Prosecutor or at the request of the victims or their legal representatives who have made a request for reparations or who have given a written undertaking to do so, determine whether measures should be adopted.'

These provisions are of critical importance to the realisation of reparations awards, in those instances where there are assets and they are traceable. However, the wording of Article $93(1)(\mathrm{k})$ refers to 'the identification, tracing and freezing or seizure of proceeds, property and assets and instrumentalities of crimes for the purpose of eventual forfeiture, without prejudice to the rights of bona fide third parties'. This would at first sight suggest that different from the clearer framework for post-conviction enforcement, ${ }^{25}$ the precautionary measures are aimed at proceeds of crime, not simply assets for eventual victims. To interpret Article 93(1)(k) as requiring a link to proceeds of crime is to place a heavy evidential burden which must be met before any assets will be frozen. In order for assets to be considered proceeds of crime, there normally would need to be evidence that the assets are 'ill-gotten gains' that were procured through the criminal activity of the accused person. This is a usual evidential burden for forfeiture proceedings, given that if convicted, perpetrators would not able to keep the ill-gotten gains; the assets would be confiscated. But arguably it is an overly onerous burden for the freezing of assets for the ultimate benefit of victims, given that an order for reparations is akin to a civil debt against a convicted perpetrator - there is no need for the convicted perpetrator to satisfy that judgment through ill-gotten gains; the judgment can be satisfied by any assets belonging to the perpetrator.

\footnotetext{
${ }^{25}$ Article 75(4) of the ICC Statute. See also, D. Donat-Cattin, Article 75, in O. Triffterer (Ed.), Commentary on the Rome Statute of the International Criminal Court. Observers' notes, Article by Article 966 (1999), 966.
} 
Despite the wording of Article 93(1)(k), so far chambers have taken an expansive view of the meaning of the provision. Chambers have included in, referred to, or annexed to arrest warrants, requests to States that they trace, freeze or seize the assets of persons named in those warrants, ${ }^{26}$ without requiring a link to the proceeds or instrumentalities of crimes. In addition, Chambers have issued separate requests to States to trace or freeze assets ${ }^{27}$ also without requiring such a restrictive nexus. However the issue is not free from debate. The interpretation of Article 57(3)(e) arose in a number of cases, including in the Lubanga ${ }^{28}$ and Kenyatta $^{29}$ cases.

In the Lubanga case, when determining whether it could seek the cooperation of States Parties to take protective measures for the purpose of securing the enforcement of a future reparation award pursuant to Article 57(3)(e), the Pre-Trial Chamber noted that 'although a first reading of article 57 (3) (e) of the Statute might lead to the conclusion that cooperation requests for the taking of protective measures under such a provision can be aimed only at guaranteeing the enforcement of a future penalty of forfeiture under article 77 (2) of the Statute, the literal interpretation of the scope of such provision is not clear, because of the reference to the "ultimate benefit of the victims". ${ }^{30}$ Not only does the Pre-Trial Chamber affirm the importance of making swift requests in order to avoid the dissipation of property or assets, nowhere in the decision does the Pre-Trial Chamber limit the subject matter to the proceeds or instrumentalities of crime.

In the Kenyatta case, in 2011, Pre-Trial Chamber I had ordered the Registrar to prepare and transmit a request for cooperation to the competent authorities of the Republic of Kenya for purposes of identifying, tracing and freezing or seizing the property and assets belonging to or under the control of Mr. Kenyatta. At a much later stage before the Trial Chamber, the

\footnotetext{
${ }^{26}$ E.g., Prosecutor v. Thomas Lubanga Dyilo, Decision on the Prosecutor's Application for Warrants of Arrest, Article 58, Annex II, ICC01/04-520-Anx2, 10 February 2006; Prosecutor v. Germain Katanga, Order on the execution of the warrant of arrest against Germain Katanga, ICC-01/04-01/07-54-tENG, 5 November 2007.

${ }^{27}$ See, e.g., Prosecutor v. Thomas Lubanga Dyilo, Request to States Parties to the Rome Statute for the Identification, Tracing and Freezing or Seizure of the Property and Assets of Mr Thomas Lubanga Dyilo, ICC-01/04-01/06-62-tEN, 31 March 2006; Prosecutor v. Germain Katanga, Request to the Democratic Republic of the Congo for the Purpose of Obtaining the Identification, Tracing, Freezing and Seizure of the Property and Assets of Germain Katanga, ICC-01/04-01/07-7-tENG 07-11-2007, 6 July 2007; Prosecutor v. Francis Kirimi Muthaura, Uhuru Muigai Kenyatta and Mohammed Hussein Ali, Decision Ordering the Registrar to Prepare and Transmit a Request for Cooperation to the Republic of Kenya for the Purpose of Securing the Identification, Tracing and Freezing or Seizure of Property and Assets of Francis Kirimi Muthaura, Uhuru Muigai Kenyatta and Mohammed Hussein Ali, ICC-01/09-02/11-42, 5 April 2011.

${ }^{28}$ Prosecutor v. Thomas Lubanga Dyilo, Decision on the Prosecutor's Application for Warrants of Arrest, Article 58, Annex II, ICC-01/04520-Anx2, 10 February 2006.

${ }^{29}$ Prosecutor v. Uhuru Muigai Kenyatta, Decision on the implementation of the request to freeze assets, Trial Chamber V(B), ICC-01/0902/11, 8 July 2014

${ }^{30}$ Prosecutor v. Thomas Lubanga Dyilo, Decision on the Prosecutor's Application for Warrants of Arrest, Article 58, 10 February 2006, para. 146.
} 
Registry brought to the attention of the Chamber the Kenyan Government's refusal to execute the Pre-Trial Chamber's request on the basis that Article 93(1)(k) of the Statute only applies at the post-conviction phase and then only to assets that could be considered to be the proceeds or instrumentalities of the crime. The Trial Chamber held that the statutory framework does not require a nexus to be established with the proceeds or instrumentalities of the crime when ordering protective measures under Article 57(3)(e). It held that the term 'forfeiture' may carry a broader meaning which encompasses an award for reparations. Referring to a teleological interpretation of Article 57(3)(e) of the Statute, and to ensure that the relevant Trial Chamber will have recourse to such assets for the purpose of an eventual order for reparations, the Trial Chamber held that it is necessary that protective measures are implemented at the earliest opportunity prior to the commencement of trial, after the issuance of a warrant of arrest or a summons to appear. Judge Henderson, in his dissent, took the view that Article 57(3)(e)of the Statute and Rule 99(1) of the Rules do not authorise a Chamber to request a State to take protective measures under Article 93 (1) of the Statute for the purposes of an order for reparations. In his view, protective measures can be taken for the purposes of eventual forfeiture, which in appropriate circumstances can be transferred to the Trust Fund and thereafter used for the benefit of the victims in an award for reparations. Under Judge Henderson's analysis therefore, the forfeiture requirements (of the assets being linked to the proceeds and instrumentalities of crime) would appear to apply to protective measures.

It is unclear how other Trial Chambers will interpret Article 57(3)(e) or whether the issue will in future be decided resolutely by the Appeals Chamber. The decision of the majority in the Kenyatta case, if it holds, is a progressive interpretation of the statutory framework which should encourage legal representatives for victims to actively engage with the Prosecution and the relevant Chambers on the issue of asset orders, for the ultimate benefit of victims. ${ }^{31}$

However, regardless of the interpretation of Article 93(1)(k) by different ICC Chambers to date, the vagueness of the statutory framework has meant that the procedures put in place by certain States Parties to cooperate with such requests have narrowly focused on the proceeds and instrumentalities of crime.32 This has been the argument of Kenya in the Kenyatta case, though as indicated, the Trial Chamber majority rejected these arguments. In so doing, it

\footnotetext{
${ }^{31}$ See, the similar approach taken in Prosecutor v. Germain Katanga, Order on the execution of the warrant of arrest against Germain Katanga, ICC-01/04-01/07-54-tENG, 5 November 2007

${ }^{32}$ See, e.g., Valerie Oosterveld, Mike Perry and John McManus, 'The Cooperation of States with the International Criminal Court' (2001-2) 25 Fordham Int'1 L.J. 767 which analyses certain domestic implementing legislation.
} 
reminded that States Parties are 'under an obligation to "promptly", pursuant to Article 93(3) of the Statute, or "without delay", pursuant to Article 97 of the Statute, engage in consultations with a view to resolving the matter'. ... 'In the case of a genuine dispute regarding the legality of a request for cooperation, a State is directed by Regulation 108(1) of the Regulations of the Court ('Regulations') to apply for a ruling from the competent Chamber.' 33

\section{II.2 Post-Conviction cooperation}

States Parties are obliged to give effect to fines and forfeitures ordered by the Court following a conviction, as well as reparations orders. Rule 217 of the Rules of Procedure and Evidence provides that: 'the Presidency shall, as appropriate, seek cooperation and measures for enforcement $[\ldots]$ as well as transmit copies of relevant orders to any State with which the sentenced person appears to have direct connection by reason of either nationality, domicile or habitual residence or by virtue of the location of the sentenced person's assets and property or with which the victim has such connection.' Rule 218(3) provides further that 'in order to enable States to give effect to an order for reparations, the order shall specify: (a) The identity of the person against whom the order has been issued; (b) In respect of reparations of a financial nature, the identity of the victims to whom individual reparations have been granted, and, where the award for reparations shall be deposited with the Trust Fund, the particulars of the Trust Fund for the deposit of the award; and (c) The scope and nature of the reparations ordered by the Court, including, where applicable, the property and assets for which restitution has been ordered.' States would not have the ability to modify the reparations orders specified by the Court. ${ }^{34}$ The correct procedure is instead for persons affected by reparations orders to appeal the Court's reparations decision.

In accordance with these provisions, it is envisioned, at least as a matter of principle, that a Trial Chamber may order reparations without having previously identified the assets. The express reference by the Appeals Chamber in the Lubanga case to regulation 117 of the Regulations of the Court, which gives the Presidency the role of monitoring the financial situation of the sentenced person on an ongoing basis, even following completion of a sentence, ${ }^{35}$ underscores this interpretation. Clearly however, it is most advantageous for

\footnotetext{
${ }^{33}$ Prosecutor v. Uhuru Muigai Kenyatta, Decision on the implementation of the request to freeze assets, paras. $25,26$.

${ }^{34}$ Rule 219.

${ }^{35}$ ICC, Prosecutor v. Thomas Lubanga, Appeals Chamber judgment, 3 March 2015, para. 104.
} 
assets to be identified much earlier in the process so that there is less chance of dissipation and they can be frozen and made available to enforce reparations orders following a conviction.

The Appeals Chamber did not address the issue as to what will happen to assets which come into the Court's possession after the closure of reparations phase of a case. The Statute does not provide a clear avenue for victims' legal representatives to seek to re-open reparations proceedings after the close of a case. Presumably, the Chamber assigned with overseeing the implementation of reparations orders would be capable of being seized if the assets are located during the enforcement process. If property or assets are located after the implementation of the reparations order is completed, the Presidency would arguably have the authority to constitute a new chamber for the purpose of determining what should transpire with those assets.

\section{Particular problem areas in the context of application}

\section{III.1 Implementing legislation}

As the Court has itself set out, 'The first obligation of States with respect to cooperation is to implement the Rome Statute in their domestic legislation and thereby provide, in particular, pursuant to article 88 procedures for "all of the forms of cooperation" specified in Part 9. Fulfilling this obligation constitutes a first step in order to ensure full cooperation with the Court. Without such implementing legislation, cooperation requests may encounter domestic legal hurdles in practice, since the legal and judicial authorities in charge of undertaking the requested measures may lack jurisdiction and power to proceed. Such implementing legislation is also likely to be necessary to set appropriate detailed procedural mechanisms. ${ }^{36}$

Yet, the vague provisions of the ICC Statute and Rules of Procedure and Evidence regarding assets and property recovery impede the practical results of such endeavours. This is compounded by the fact that the obligations of States Parties to cooperate with the Court and aid in the process of uncovering and transferring assets and property are to be implemented in accordance with the "procedure of national law. ${ }^{37}$ States Parties must ensure that the

\footnotetext{
${ }^{36} \mathrm{ICC}$, Report of the Court on International Cooperation and Assistance, in Assembly of States Parties, Report of the Bureau on cooperation, ICC-ASP/8/44, 15 November 2009, Annex 1, para. 15.

${ }^{37}$ Article 93(1) of the Statute.
} 
necessary procedures are in place at the national level in order to be able to execute a request from the Court to this end. While the Statute makes clear that the absence of adequate domestic laws and procedures does not justify non-compliance, ${ }^{38}$ in reality however, few States have sufficiently robust procedures to respond to asset and property requests emanating from the Court. States' implementing legislation and the associated procedures put in place by States to foster cooperation are often insufficiently robust, clear or sufficient to do the job. Inevitably, gaps result in delays and inefficiencies when faced with a cooperation request which allows for funds and property to be transferred out of a jurisdiction or dissipated with relative ease.

In the case of non-States Parties, there is no overriding obligation to cooperate with the Court though those non-States Parties who wish to cooperate with the Court may do so, 'on the basis of an ad hoc arrangement, an agreement with such States or any other appropriate basis. $^{\text {, }} 39$

If assets are located on the territory or in the control of non-States Parties, the Court, or the individual recipients of reparations orders, would need to advocate for the recognition of the ICC order in that jurisdiction. If a non-State Party has entered into an ad hoc arrangement or an agreement with the Court, and thereafter fails to cooperate with requests pursuant to any such arrangement or agreement, the Court may so inform the Assembly of States Parties or, where the Security Council referred the matter to the Court, the Security Council. ${ }^{40}$ The Statute does not specify whether arrangements or agreements the Court enters into can be revoked or altered by non-States Parties or the terms by which any such alterations may be made. The ability for the Court to ensure the enforcement of such agreements in the absence of the good faith will of the State to comply seems minimal at best.

\section{III.2 The disposition of assets subject to sanctions regimes and other parallel freezing orders}

In certain cases, assets belonging to perpetrators may have been frozen pursuant to Security Council or other sanctions regimes, and the ability of the ICC to obtain control of those assets for the purposes of reparations is untested. A number of situation countries have been the subject of UN Security Council sanctions regimes, with several defendants featuring directly

\footnotetext{
${ }^{38}$ Article 88 of the Statute.

${ }^{39}$ Article 87(5)(a) of the Statute.

${ }^{40}$ Article 87(5)(b) of the Statute.
} 
on lists of persons whose property or assets should be frozen. The relationship between those sanctions regimes and the ICC's cooperation regime are untested. As a matter of principle, obligations pursuant to Article 103 of the UN Charter would trump any obligations States Parties have to cooperate with the Court. ${ }^{41}$ Thus, States Parties faced with competing requests from the ICC and from the Security Council may be compelled to act first and foremost on the Security Council requests.

This challenge of dealing with such competing obligations has been noted by the Bureau of the Assembly of States Parties' facilitator on cooperation, and States Parties have been encouraged to 'handle such requests on the basis of article 93, paragraph 9(b), of the Rome Statute, respectful of Article 103 of the United Nations Charter' ${ }^{2}$ and 'continue to provide political and diplomatic support to the Court, and, where possible, consider approaching the United Nations Security Council (hereinafter UNSC) and/or the sanctions committees, with a view to finding arrangements that would allow the UNSC and sanctions committees to share more information with the Court with regard to assets. ${ }^{43}$ Further, States Parties have been requested to 'be mindful of how the wording of UNSC resolutions may affect the Court's execution of its mandate, and, where possible, try to influence the wording of such resolutions to take into account the operational needs of the Court. The possibility of adding provisions to resolutions allowing for (partial) unfreezing of frozen assets to allow for payment of Court-related legal fees could be explored. ${ }^{44}$

However the ability of the Security Council to order the transfer of assets to the Court is untested. The Relationship Agreement between the International Criminal Court and the United Nations ${ }^{45}$ provides no guidance. It has been recommended that 'when cognisant that the same assets could be requested to be frozen or identified by the Court, [States should] take necessary measures on the national level so that information gathered in connection with the implementation of the UNSC resolution could be shared with the national focal point or the relevant national authority for Court cooperation. ${ }^{46}$ Yet arguably, the Court should be engaging the Security Council directly, and negotiating further provisions to outline the

\footnotetext{
${ }^{41}$ See, Conor McCarthy, Reparations and Victim Support in the International Criminal Court, Cambridge: Cambridge University Press, 2012, 307-8

${ }^{42}$ ICC, Summary of the 1 October 2012 workshop on cooperation, including proposals and suggestions from the participants, 23 October 2012, Annex 2, para B(11).

${ }^{43}$ Ibid, para. $\mathrm{B}(9)$.

${ }^{44} \mathrm{Id}$, para. $\mathrm{B}(10)$

${ }^{45}$ Concluded on 4 October 2004.

${ }^{46}$ ICC, Summary of the 1 October 2012 workshop on cooperation, including proposals and suggestions from the participants, 23 October 2012, Annex 2, para B(12).
} 
modalities for sharing of information regarding competing requests, and where possible, ensuring that funds frozen pursuant to Security Council resolutions can as appropriate contribute to the fulfilment of the Court's reparations orders. Importantly, in 2012, the Prosecutor noted that 'Since the opening of the situation, the Office has been in contact with the UN Sanctions Committee, which is assisted by a Panel of Experts and with Interpol to coordinate its investigative efforts in relation to the assets of the suspects. The Court has sent at the end of September requests for assistance to Libya, State Parties, and five UN Security Council non-State Parties to identify, trace, seize and freeze all the personal assets belonging to the suspects. The Office strongly encourages the Security Council and States to assist the Court in identifying and isolating these assets. ${ }^{47}$ These are crucial steps.

There are several instances in which property or other assets frozen pursuant to Security Council procedures have subsequently been unfrozen, however the ICC's outstanding requests are not known to have featured in the analysis of whether or how these should be unfrozen and who should ultimately benefit. For instance, some of the Libyan frozen assets have progressively been unfrozen 'for the benefit of the Libyan people, ${ }^{48}$ even though the ICC still has an open case against Abdallah Al-Senussi.

\section{III.3 Competing claims for assets}

In the event that property or assets are located and frozen, a question arises as to the circumstances and modalities in which they will be made accessible for the purposes of reparations. The ICC will have a number of uses for the assets which go beyond reparations, such as for instance, the payment of defendants' legal costs that had, prior to the location of the assets, been covered by legal aid. Rule 21(5) of the Rules of Procedure and Evidence provides that: "where a person claims to have insufficient means to pay for legal assistance and this is subsequently found not to be so, the Chamber dealing with the case at that time may make an order of contribution to recover the cost of providing counsel.' However, in accordance with Rule 221(1) of the Rules of Procedure and Evidence, the Presidency, which

\footnotetext{
${ }^{47}$ Prosecutor of the ICC, Statement to the United Nations Security Council on the situation in Libya pursuant to UNSCR 1970 (2011), 2 November 2011, para. 13.

${ }^{48}$ The UN sanctions against the Libyan State and officials associated with the Gaddafi regime were progressively modified, reducing the scope of their application as the conflict against the Gaddafi regime came to a conclusion. For instance, on 16 September 2011 the Security Council adopted Resolution 2009 which inter alia lifted the asset freeze against certain State institutions. The Security Council recalled its determination to ensure that asset frozen pursuant to resolutions 1970 (2011) and 1973 (2011) shall as soon as possible be made available to and for the benefit of the people of Libya' and underscored 'the importance of making these assets available in a transparent and responsible manner in conformity with the needs and wishes of the Libyan people.'
} 
is mandated to decide on the disposition or allocation of such assets, 'shall give priority to the enforcement of measures concerning reparations to victims'.

While in principle Rule 221 clarifies that reparations will trump other claims emanating from the Court, and the importance of this prioritisation has been underscored by the Assembly of States Parties, ${ }^{49}$ it is nonetheless possible that the timing of the operation of the different procedures may inhibit the operation of the rule. Rule 221 arguably operates after conviction, whereas rule 21(5) may operate at an earlier stage. Thus, it is possible that there will be a dissipation of assets through the operation of Rule 21(5) prior to the end of the trial, which will work against the ultimate benefit of victims. For instance, the Pre-Trial Chamber partially allowed some of Jean-Pierre Bemba Gombo's assets that had been frozen by Portugal to be unfrozen, in order to allow for him to pay for his defence and to provide the minimum upkeep to his family. ${ }^{50}$

Further it is not evident how national courts will deal with the competing claims for assets, or how they will assign priorities in order to adjudicate between these claims. For instance, reparations orders against former heads of State or senior officials may give rise to competing claims against the perpetrator for corruption or misappropriation of State funds. There may also be additional creditors and/or victims who did not apply through the ICC reparations process, whose claims would need to be adjudicated by national courts. The Rome Statute deals with competing surrender or extradition requests, ${ }^{51}$ but not competing requests for other forms of cooperation such as assets. When there are competing surrender or extradition requests, there is an obligation on the State with the competing requests to notify the Court and the requesting State of that fact, and if the requesting State is a State Party and the case is determined to be admissible before the Court, the Statute determines that the Court has priority. ${ }^{52}$ In contrast, the Rome Statute provides no real answer in relation to competing asset requests. There is simply the obligation on States Parties pursuant to Articles 93(3) and 97 of the Statute, to engage in consultations with a view to resolving the matter, and/or to apply for a ruling from the competent Chamber.

\footnotetext{
${ }^{49}$ Assembly of States Parties, Resolution on "Victims and affected communities, reparations and Trust Fund for Victims", December 2014, para. 12.

${ }^{50}$ Prosecutor v. Jean Pierre Bemba Gombo, Decision on the Defence's Application for Lifting the Seizure of Assets and Request for Cooperation to the Competent Authorities of Portugal, ICC-01/05-01/08-251-Anx, 10 October 2008.

${ }^{51}$ Article 90 of the ICC Statute.

${ }^{52}$ Article 90(2) and (3) of the Statute.
} 
Article 93(1)(k) underscores that measures can be taken "without prejudice to the rights of bona fide third parties.' Yet, if there are indeed bona fide third parties, it is unclear how these would be dealt with. It is unclear whether the Court would take upon itself the task of determining whether the claims of third parties are bona fide. Rule 99(3) indicates that' If an order is made without prior notification, the relevant Chamber shall request the Registrar, as soon as is consistent with the effectiveness of the measures requested, to notify those against whom a request is made and, to the extent possible, to any interested persons or any interested States and invite them to make observations as to whether the order should be revoked or otherwise modified.' But it is unclear how this provision would operate in practice. Presumably the victims before the ICC will be just as bona fide as any other bona fide third party. On one reading, the beneficiaries of an ICC reparations awards may only benefit from assets if there are no other parties with a claim to those assets.

There are frameworks in anti-corruption and money laundering treaties that may be useful to peruse for ideas but they do not apply as such. The closest example is perhaps the Swiss attempts to broker an equitable solution when Philippine recipients of an American Alien Tort Claims Act judgment in Hawaii sought to enforce their award against assets frozen in Switzerland, and at the same time the Philippines Government was seeking return of the Marcos' ill-gotten gains - misappropriation of State funds. But this brokering of a solution was not perfect, nor can it be easily replicated in the context of the ICC. In the Swiss case, Switzerland was in possession of the disputed assets was faced with the decision as to how best to equitably allocate those assets. In the case of the ICC, invariably the Court will not be in possession of the assets.

\section{Conclusion}

Clearly there remain a lot of unanswered questions and several important gaps in the applicable legal and procedural frameworks which combine to make the prospects of asset recovery both daunting and remote. Given victims' limited procedural rights before the ICC, their lack of standing before the sanctions committees of the United Nations and the extreme difficulties if not impossibility they will encounter to access courts in the countries where property and other assets may be located, the Court must work with States Parties and nonStates Parties alike, and intergovernmental organisations in order to resolve the many 
remaining uncertainties. This must be done at the earliest possible opportunity if the reparations regime of the ICC is to live up to its promise. 